\title{
Induction of a Negative Autocrine Loop by Expression of Sst2 Somatostatin Receptor in NIH 3T3 Cells
}

\author{
Isabelle Rauly, Nathalie Saint-Laurent, Nathalie Delesque, Louis Buscail, Jean-Pierre Estève, Nicole Vaysse, \\ and Christiane Susini \\ INSERM U151, Institut Louis Bugnard, CHU Rangueil, 31054 Toulouse, Cedex, France
}

\begin{abstract}
The somatostatin receptor subtype sst 2 mediates both activation of a tyrosine phosphatase activity and inhibition of cell proliferation induced by somatostatin analogues. In the absence of exogenous ligand, expression of sst2 in NIH 3T3 cells resulted in inhibition of cell growth. Polymerase chain reaction coupled to reverse transcription demonstrated that expression of sst 2 in NIH $3 \mathrm{~T} 3$ cells stimulated the expression of preprosomatostatin mRNA accompanied by a production of immunoreactive somatostatin-like peptide which corresponded predominantly to somatostatin 14 . Moreover anti-somatostatin antibodies suppressed sst2-promoted inhibition of cell proliferation. Inhibition of cell proliferation associated with increased secretion of somatostatin-like immunoreactivity was also observed after expression of sst 2 in human pancreatic tumor cells BxPC3 devoid of endogenous receptors. In addition, expression of sst 2 in NIH 3 T3 cells was associated with the constitutive activation of tyrosine phosphatase PTP1C that resulted from enhanced expression of the protein. Blocking of PTP1C tyrosine phosphatase activity with orthovanadate or that of PTP1C protein with antisense PTP1C oligonucleotides decreased the sst2-induced inhibition of cell proliferation. These results, taken together, show that expression of sst2 in NIH 3T3 cells generated a negative autocrine loop by stimulating sst2 ligand production and amplifying PTP1C sst2-transducer. Sst2/ligand may function as a determinant factor involved in the negative growth control of cells. (J. Clin. Invest. 1996. 97:1874-1883.) Keys words: somatostatin - tyrosine phosphatase PTP1C • proliferation • autocrine secretion
\end{abstract}

\section{Introduction}

Somatostatin, is a widely distributed neuropeptide that has been localized to numerous mammalian tissues and shown to inhibit diverse cellular processes including secretion and proliferation (1-3). The biological effect of somatostatin is mediated by G-protein coupled receptors that mediate a variety of signal transduction pathways including adenylate cyclase, ionic conductance channels and protein dephosphorylation (3-7).

Address correspondence to Dr. Christiane Susini, Ph.D., INSERM U 151, Biologie et Path Digest, Institut Louis Bugnard, CHU Rangueil, Bt L3, 1 Ave Jean Poulhes, F31054 Toulouse Cedex, France. Phone: 61322407; FAX: 62264012.

Received for publication 11 May 1995 and accepted in revised form 2 February 1996.

J. Clin. Invest.

(C) The American Society for Clinical Investigation, Inc.

0021-9738/96/04/1874/10 \$2.00

Volume 97, Number 8, April 1996, 1874-1883
Somatostatin or its analogues affect the growth of various normal and tumor cells. This effect may involve indirect mechanisms including inhibition of synthesis and secretion of growth factors and hormones $(8,9)$. However, much evidence exists for a direct antiproliferative effect of somatostatin or its analogues, which is exerted through specific somatostatin receptors on normal and neoplastic cells including pituitary, pancreatic, breast, colon and prostate tumors cells (9-11). In pancreatic tumor cells, we and others, have demonstrated that analogues of somatostatin antagonize the mitogenic effect of growth factors acting on tyrosine kinase receptors such as epidermal growth factor and fibroblast growth factor $(12,13)$. Furthermore, these analogues cause the stimulation of a membrane tyrosine phosphatase that may be involved in the intracellular mechanism of somatostatin-induced growth inhibition $(7,12,14)$.

Five somatostatin receptor subtypes termed sst1-5 have been recently cloned (15-18). They have a tissue-specific distribution and can functionally couple to diverse signal transduction pathways (19). We recently expressed the cloned somatostatin receptors in different cell types and demonstrated that subtype sst 2 mediates the inhibition of cell growth induced by somatostatin analogues and this effect involved the activation of a tyrosine phosphatase $(20,21)$. We identified the somatostatin-sensitive tyrosine phosphatase as the $66-\mathrm{kD}$ tyrosine phosphatase containing Src homology 2 (SH2) domains, PTP1C (also called SHPTP1, HCP) (22-25). The role of sst 2 in the negative control of cell proliferation is strengthened by the presence of this receptor subtype in various human and rat tumor cell lines such as pancreatic, breast and small cell lung cancer cell lines that respond in vitro to the growth-inhibitory effect of somatostatin analogues $(26,27)$.

Besides its well known neurohormonal regulatory role, there is emerging evidence for the hypothesis that somatostatin may act as an autocrine/paracrine regulatory factor. Indeed, a variety of normal cells, including endocrine and lymphoid cells, that synthesize endogenous somatostatin are known to express somatostatin receptors (28-30). Furthermore, immunoreactive somatostatin has been found in various types of somatostatin receptor-positive tumor cell lines such as breast cancer cells and colonic tumor cells $(31,32)$ and somatostatin mRNA was detected in a wide variety of neuroendocrine tumors known to express somatostatin receptors $(33,34)$. It is, however, not yet documented whether somatostatin can play a negative autocrine role in such cells.

In the present study, we demonstrated that the expression of sst 2 in mouse fibroblast NIH 3 T3 cells causes the constitutive activation of the receptor that leads to an inhibition of cell growth which is independent of added ligand. The activation of sst2 resulted from sst2-induced expression of both sst2ligand and -signal transduction system resulting in the creation of a negative autocrine somatostatin-receptor loop. Finally, we report that the negative autocrine loop can also be created by 
expression of sst 2 in another cell type devoid of endogenous sst2, the human pancreatic tumor BXPC3 cells.

\section{Methods}

Reagents. $\left.{ }^{33} \mathrm{P}\right] \mathrm{ATP}(3,000 \mathrm{Ci} / \mathrm{mmol})$ was from Isotopchim (France). Oligonucleotides were synthesized by Eurogentec (Seraing, Belgium). Somatostatin was a kind gift from Dr. L. Moroder (Munich, RFA). SMS 201-995 and Tyr ${ }^{3}$ SMS were generously provided by Dr. Bruns (Sandoz, Switzerland) and fibroblast growth factor-2 (FGF2) was a gift from Dr. H. Prats (INSERM, Toulouse, France). RNAzol B was from Bioprobe (Montreuil $/$ /Bois, France). Taq polymerase was from Beckman (Gagny, France). Moloney murine Leukemia virus reverse transcriptase and lipofectin were from GIBCO BRL (Cergy Pontoise, France). Somatostatin antibodies were from Neosystem (Strasbourg, France). Sense and antisense oligonucleotides were synthesized and purified by Eurogentec (Seraing, Belgium).

Cell culture and transfections. The human sst1 and human sst2 were stably expressed in mouse fibroblasts NIH 3T3 cells using the recombinant dicistronic mammalian expression vector containing the simian virus 40 replication origin, the cytomegalovirus promoter, the encephalomyocarditis virus leader, and the geneticin-resistance gene as previously described (20). Cells were transfected using calcium-phosphate precipitation and geneticin-resistant clones were selected and examined for their ability to bind $\left[{ }^{125} \mathrm{I}_{-} \mathrm{Tyr}^{11}\right]$ somatostatin or $\left[{ }^{125} \mathrm{I}_{-} \mathrm{Tyr}^{3}\right] \mathrm{SMS}$ as described (20). Four clones expressing sst2 and one clone expressing sst1 were selected and cultured in DME supplemented with $10 \%$ FCS and $0.4 \mathrm{mg} / \mathrm{ml}$ geneticin.

Human pancreatic tumor cells BXPC3 were transfected with the sst2 expression vector using lipofectin reagent. Geneticin-resistant clones were selected by binding studies using $\left[{ }^{125} \mathrm{I}_{-} \mathrm{Tyr}^{3}\right] \mathrm{SMS}$ as tracer. One clone that expressed sst 2 with a $K_{\mathrm{d}}$ of $0.8 \mathrm{nM}$ and a binding capacity of $20 \mathrm{fmol} / \mathrm{mg}$ protein (determined by Scatchard analysis) was used for further experiments. Wild NIH $3 \mathrm{~T} 3$ and BXPC3 cells were also transfected with a mock dicistronic vector devoid of sst 2 cDNA and used as the control clones.

Binding studies. Cells were cultured in 35-mm diameter dishes in DME supplemented with 10\% FCS for $48 \mathrm{~h}$ as described (20). After washing twice with Krebs/Hepes buffer, binding was performed at $25^{\circ} \mathrm{C}$ for $120 \mathrm{~min}$ in a final volume of $1.5 \mathrm{ml}$ of Krebs/Hepes buffer ( $\mathrm{pH}$ 7.4) containing bovine serum albumin at $15 \mathrm{mg} / \mathrm{ml}$, soybean trypsin inhibitor at $0.3 \mathrm{mg} / \mathrm{ml}$, bacitracin at $0.5 \mathrm{mg} / \mathrm{ml}$, and $30 \mathrm{pM}$ of

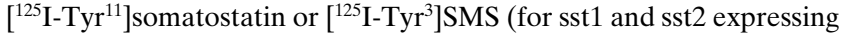
cells, respectively). Nonspecific binding was determined in the presence of $1 \mu \mathrm{M}$ somatostatin or SMS 201-995. The cells were then washed and lysed in $0.1 \mathrm{~N} \mathrm{NaOH}$ and specific binding was quantified.

Cell growth assay. Cells were plated in $35-\mathrm{mm}$ diameter dishes $\left(12 \times 10^{4}\right.$ cells per dish $)$ in DME supplemented with $10 \%$ FCS. After an overnight attachment phase, the medium was changed and cells were grown in DME supplemented with $10 \%$ FCS or without serum in absence or presence of $0.1 \mathrm{nM} \mathrm{FGF2}$. Growth was measured after indicated times by cell counting using a Coulter model ZM counter (Coulter Electronics), after treatment of cells with $0.05 \%$ trypsin and $0.02 \%$ EDTA as described (20).

For oligonucleotide treatment, NIH 3 T3 cells were grown in 24well plates $\left(6 \times 10^{4}\right.$ cells per well $)$ in DME supplemented with $10 \%$ FCS and allowed to attach overnight. $5 \mu \mathrm{M}$ PTP1C antisense (5'-GTAAAAACTCCTAGAGAT-3' and 5'-CACCATCCTGGGGTT-3'), or sense (5'-ATCTCTAGAGTTTTTAC-3' and 5'-AACCCCAGGATGGTG-3') phosphorothioate oligonucleotides were added twice daily for $4 \mathrm{~d}$. Then cell number was measured.

Tyrosine phosphatase assay. The substrate poly(Glu, Tyr) was phosphorylated with $\left[\gamma^{33} \mathrm{P}\right] \mathrm{ATP}$ as described (20). Cells were washed and quickly lysed in liquid nitrogen in a $50 \mathrm{mM}$ Tris buffer, $\mathrm{pH} 7.4$, containing $0.3 \mathrm{mg} / \mathrm{ml}$ soybean trypsin inhibitor and $0.1 \mathrm{mM}$ phenylmethylsulfonyl fluoride. After tawing, the homogenate $(1 \mu \mathrm{g}$ protein/ assay) was assayed for tyrosine phosphatase activity as described (20) in a $100 \mu \mathrm{l}$ reaction mixture containing $50 \mathrm{mM}$ Tris ( $\mathrm{pH} 7)$, bovine serum albumin at $1 \mathrm{mg} / \mathrm{ml}, 30,000 \mathrm{cpm}$ of ${ }^{33} \mathrm{P}$-poly(Glu, Tyr) and $5 \mathrm{mM}$ dithiothreitol. Tyrosine phosphatase activity was expressed in pmol of phosphate released per min at $30^{\circ} \mathrm{C}$ from radiolabeled substrate.

Reverse transcription-polymerase chain reaction (RT-PCR). Total RNA was extracted by a procedure derived from that of Chomczynski and Sacchi (35). Cells were lyzed in RNAzol B for $10 \mathrm{~min}$ at $4^{\circ} \mathrm{C}$ and RNA was extracted as described (36). For reverse transcription, total RNA was first denatured at $94^{\circ} \mathrm{C}$ for $10 \mathrm{~min}$ and immediately chilled on ice. First-strand cDNA synthesis was then carried out with total RNA in $50 \mathrm{mM}$ Tris- $\mathrm{HCl}$ buffer ( $\mathrm{pH} 8.3$ ) containing $200 \mathrm{U}$ of Moloney murine leukemia virus reverse transcriptase, $26.5 \mu \mathrm{M}$ oli$\operatorname{god}(\mathrm{T}), 1 \mathrm{mM}$ dNTP, $20 \mathrm{U}$ RNAsin, $10 \mathrm{mM}$ dithiothreitol, $75 \mathrm{mM}$ $\mathrm{KCl}, 3 \mathrm{mM} \mathrm{MgCl}$ in a final volume of $20 \mu \mathrm{l}$. The sample was incubated for $10 \mathrm{~min}$ at $23^{\circ} \mathrm{C}$ followed by $2 \mathrm{~h}$ at $39^{\circ} \mathrm{C}$. The RT mixture was then chilled on ice and diluted two-fold with sterile water. PCRs were carried out as described (36) with $1.25 \mathrm{U}$ of Taq polymerase, $1 \mu \mathrm{M}$ specific sense and antisense primers, $250 \mu \mathrm{M}$ of dNTPs, in $10 \mathrm{mM}$ Tris- $\mathrm{HCl}$ buffer ( $\mathrm{pH}$ 9) containing $50 \mathrm{mM} \mathrm{KCl}, 1.5 \mathrm{mM} \mathrm{MgCl}_{2}, 0.01 \%$ Triton X-100 in a final volume of $50 \mu \mathrm{l}$. After denaturation of the sample at $94^{\circ} \mathrm{C}$ for $10 \mathrm{~min}, \mathrm{PCR}$ was carried out on a DNA Thermal Cycler (Techné Laboratories, Princeton) for varying sequential (2535) cycles with denaturation at $94^{\circ} \mathrm{C}$ for $1 \mathrm{~min}$, annealling at $51-62^{\circ} \mathrm{C}$ for $1 \mathrm{~min}$, and extension at $72^{\circ} \mathrm{C}$ for $1.5 \mathrm{~min}$. The amplification was terminated by a final extension step at $72^{\circ} \mathrm{C}$ for $10 \mathrm{~min}$. The following pairs of mouse specific primers for PTP1C: sense 5'GTCTCCACCAAGGGG3' and antisense primer 5'CTTTGTTCTTCTCCTTGTC3' (24); mouse preprosomatostatin: sense 5'TCTGCATCGTCCTGGCTTTGGG3' and antisense primer 5'AGGGTCAAGTTGAGCATCGGG3' (37) and $\beta$-actin: sense 5'TCACGCCATCCTGCGTCTGGACT3' and antisense primer 5'CCGGACTCATCGTACTCCT3' (38) produced DNA fragments of 352 base pairs (bp), 408 and $582 \mathrm{bp}$ for PTP1C, somatostatin and $\beta$-actin cDNA respectively. PCR samples were analyzed on a $7.5 \%$ polyacrylamide gel. Gels were stained with ethidium bromide and quantification was determined by image analysis (Biocom apparatus) as described (36). To standardize the results and to correct any variation in RNA content and cDNA synthesis in different preparations, the intensity of each PCR product was evaluated by comparison with that of the corresponding marker used as a standard and normalized on the basis of its $\beta$ actin content. To confirm that PCR products resulted from cDNA templates rather than from genomic DNA, reactions were also carried out in the absence of reverse transcriptase during the RT procedure.

Somatostatin radioimmunoassay. Cells were cultured for $48 \mathrm{~h}$ in DME supplemented with $10 \%$ FCS $\left(10^{6}\right.$ cells/dish). Pooled culture media ( $30 \mathrm{ml} /$ assay) were collected and acidified with trifluoroacetic acid and concentrated using SepPak $\mathrm{C}_{18}$ cartridges (Waters, Les Ulis, France). The adsorbed peptides were eluted with $80 \%$ acetonitril, $0.1 \%$ trifluoroacetic acid. The eluates were evaporated under vacuum. The dried samples were analyzed for immunoreactivity. Cells were washed twice, extracted in $\mathrm{H}_{2} \mathrm{O}$ and boiled for $15 \mathrm{~min}$. Somatostatin-like immunoreactivity was measured in media and cell extracts by radioimmunoassay with rabbit antibody (kindly provided by Dr. Chayvialle, INSERM U 45 Lyon) directed against the central sequence of somatostatin 14 and used at 1:80,000 dilution, the radioligand $\left[\mathrm{I}^{125} \mathrm{Tyr}^{11}\right.$ somatostatin] and the standard somatostatin 14 as described (39). This assay detects somatostatin 14 and molecular forms extended at the amino terminus of somatostatin 14, including somatostatin 28 and prosomatostatin. The minimal detectable dose was 1 fmol (1.6 pg)/tube.

Gel filtration chromatography. Pooled cell culture media $(2,000$ $\mathrm{ml}$ ) from NIH3T3 cells expressing sst2 cultured in DME supplemented with $10 \%$ FCS for $48 \mathrm{~h}$ were acidified and concentrated using SepPak $\mathrm{C}_{18}$ cartridges. The adsorbed peptides were eluted with $80 \%$ acetonitrile, $0.1 \%$ trifluoroacetic acid. The eluate was evaporated and the dried sample was extracted with $10 \%$ acetic acid and soluble material was applied to a Sephadex G-50 column $(1.5 \times 90 \mathrm{~cm})$ equilibrated in $10 \%$ acetic acid. Fractions $(2.6 \mathrm{ml})$ were collected at a flow 


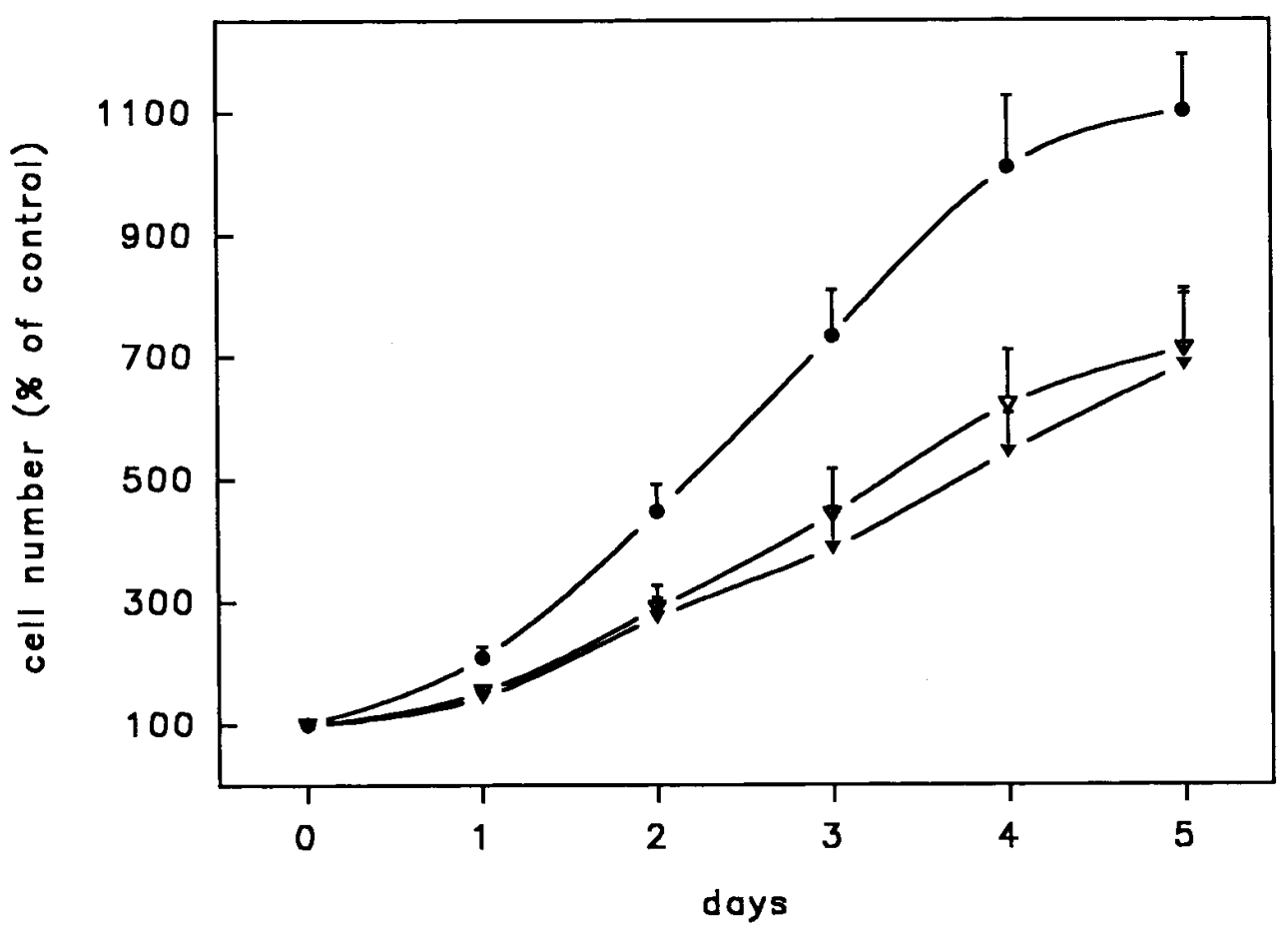

Figure 1. Effect of expression of sst 2 on NIH 3 T3 cell growth. Clonal cell lines were derived from NIH 3T3 cells stably transfected with the dicistronic vector alone (control, $\bigcirc$ ) and the vector encoding human sst 2 (clones $2 / 5$, $\nabla$ and $2 / 1, \boldsymbol{\nabla}$ ), respectively (20). Cells $\left(12 \times 10^{4}\right.$ per 35 -mm plate $)$ were grown in DME supplemented with $10 \%$ FCS allowed to attach overnight (time 0 ) and then cultured for $5 \mathrm{~d}$ in DME supplemented with $10 \%$ FCS. At indicated times, cell growth was measured by cell counting. Results are expressed as the percent of cell number obtained for the control clone at time 0 . Values are mean \pm SEM (vertical lines) of four experiments in triplicate. Values of clonal cell lines $2 / 5$ and $2 / 1$ are significantly different from control cell line $(P<0.05)$. rate of $15.6 \mathrm{ml} / \mathrm{h}$, lyophilized and somatostatin-like peptides were evaluated using radioimmunoassay. A same volume of fresh DME containing $10 \%$ FCS was subjected to the same protocol for analysis of immunoreactive somatostatin peptides present in added FCS. The column was calibrated with $1 \mathrm{ng}$ somatostatin 14 and $1 \mathrm{ng}$ somatostatin 28 applied to the column and measured by radioimmunoassay of the column effluent.

Immunoblotting and immunoprecipitation. To generate polyclonal anti-PTP1C antibodies, a peptide corresponding to a carboxyl region (EKVKKQRSADKEKSKGS) of mouse PTP1C was synthesized and conjugated to keyhole limpet hemocyanin (Neosystem, Strasbourg, France) and injected into male rabbits. The anti-PTP1C antibodies were then affinity purified by protein A-Sepharose chromatography. For immunoblotting experiments, cells were lysed in $1 \mathrm{ml}$ of ice-cold lysis buffer containing $50 \mathrm{mM}$ Tris- $\mathrm{HCl}$, (pH 7.5), $150 \mathrm{mM} \mathrm{NaCl}$, 2 mM EDTA, 1\% NP-40, 0.5\% deoxycholate, $0.1 \%$ sodium dodecyl sulfate, $10 \%$ glycerol, $0.1 \mathrm{mM}$ phenylmethylsulfonyl fluoride, $0.03 \%$ soybean trypsin inhibitor. Samples of solubilized cells or particulate and cytosolic fractions were subjected to electrophoresis as described by Laemmli (40) on a 7.5\% polyacrylamide gel and the proteins were electrotransferred to Immobilon membrane (Millipore, Les Ulis, France) as previously described (36). The membranes were saturated with 5\% dried milk in phosphate buffer saline Tween 20 (PBST), pH 7.6 and then incubated for $3 \mathrm{~h}$ at room temperature with anti-PTP1C antibodies at a 1:1,000 dilution. After washing three times with PBST, the detection of bound antisera was performed with horseradish peroxidase-labeled anti-antibody. Immunoblots were developed using the Amersham ECL detection system. The intensity of the bands was determined by image analysis using a Biocom apparatus. For immunoprecipitation, cell lysates $(200-400 \mu \mathrm{g})$ were incubated with $50 \mu \mathrm{l}$ antibody prebound to Sepharose-protein A beads for $4 \mathrm{~h}$ at $4^{\circ} \mathrm{C}$. The immunoprecipitates were then washed as described (36) once in buffer containing $50 \mathrm{mM}$ Tris- $\mathrm{HCl}(\mathrm{pH} 7.6), 150 \mathrm{mM} \mathrm{NaCl}, 0.03 \%$ soybean trypsin inhibitor and $0.1 \% \mathrm{NP}-40$, twice in $50 \mathrm{mM}$ Hepes buffer containing $150 \mathrm{mM} \mathrm{NaCl}, 0.03 \%$ soybean trypsin inhibitor and $0.1 \% \mathrm{NP}-40$, twice in $40 \mathrm{mM}$ MES buffer containing $1 \mathrm{mM}$ dithiothreitol, $0.03 \%$ soybean trypsin inhibitor $(\mathrm{pH} 5.0)$ and once in $50 \mathrm{mM}$ Tris- $\mathrm{HCl}$ buffer ( $\mathrm{pH} 7.0$ ) containing $5 \mathrm{mM}$ dithiothreitol, $5 \mathrm{mg} / \mathrm{ml}$ bacitracin, $0.03 \%$ soybean trypsin inhibitor and $0.2 \%$ bovine serum al- bumin. The immune complex was then used for subsequent assays of tyrosine phosphatase activity.

Statistical analysis. Statistical comparison between control cells and cells expressing sst2 or between treated and non treated cells were performed using Student's paired $t$-test.

\section{Results}

Stable expression of sst 2 induced an inhibition of NIH $3 T 3$ cell growth. Somatostatin receptor sst 2 was initially stably expressed in NIH 3T3 cells (20). Several geneticin-resistant clones were obtained and sst 2 receptors were characterized by binding studies using [ $\left.{ }^{125} \mathrm{I}_{-} \mathrm{Tyr}^{3}\right] \mathrm{SMS}$ as tracer (20). Among them, the clones $2 / 5$ and 2/1 expressed sst 2 with an equilibrium dissociation constant $\left(K_{\mathrm{d}}\right)$ of $0.38 \pm 0.04$ and $0.3 \pm 0.01 \mathrm{nM}$ and a binding capacity of $2.7 \pm 0.9$ and $3.3 \pm 1 \mathrm{fmol} / 10^{6}$ cells respectively (mean $\pm \mathrm{SD} ; n=2$ ), as determined by Scatchard analysis. We have previously demonstrated, in the NIH 3 T3 expressing sst 2 clones, that somatostatin analogues, RC-160 and SMS, inhibited serum- and basic fibroblast growth factor-induced cell proliferation and stimulated a tyrosine phosphatase activity but had no effect on NIH 3T3-control clone (20). Introduction of exogenous sst2 gene had an unexpected effect on the growth of sst2-transfected cells which was dramatically reduced compared with that of plasmid-transfected control cells. Kinetic studies of cell growth of the two NIH 3 T3 clonal cell lines expressing sst2, 2/5 and 2/1, revealed that the decrease of proliferation was significant after $24 \mathrm{~h}$ of culture in serum-containing medium and remained during all the time of the experiment (Fig. 1). After $5 \mathrm{~d}$ of culture, the proliferation of the two clones expressing sst $2,2 / 5$ and $2 / 1$, was reduced by $37 \pm 5$ and $38 \pm 6 \%$ (mean \pm SEM, $n=4, P<0.01)$ respectively. Two other different clones expressing sst 2 were tested and gave the same results (not shown). In contrast, expression of sst1 in NIH 3 T3 cells did not modify cell growth (not shown). 


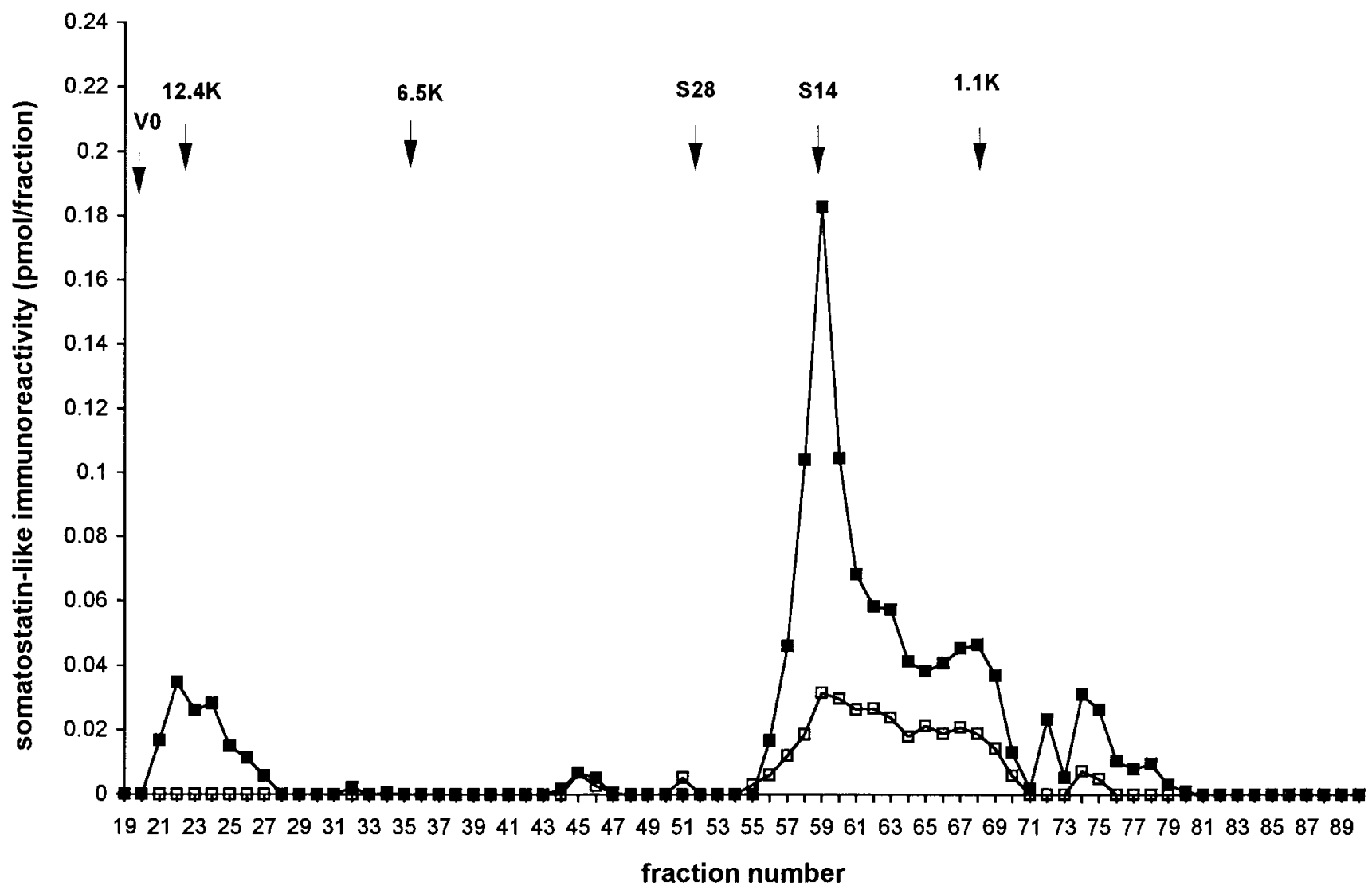

Figure 2. Somatostatin-like immunoreactivity profile after Sephadex G-50 filtration of media from NIH3T3 cells expressing sst2 (ם) and fresh DME with $10 \%$ FCS ( $\square$ ). Cells expressing sst 2 were cultured for $48 \mathrm{~h}$ in DME with $10 \%$ FCS and cell media $(2,000$ ml) were collected and treated as described in Methods. After extraction with acetic acid, the supernatant was applied to a Sephadex G-50 column equilibrated and eluated with $10 \%$ acetic acid. Each fraction $(2.6 \mathrm{ml}$ collected every $10 \mathrm{~min}$ ) was lyophilized and its immunoreactivity assayed by RIA. A similar analysis was also performed on a same volume of fresh DME containing $10 \%$ FCS. Arrows indicate the exclusion volume $\left(\mathrm{V}_{0}\right)$ and the elution position of cytochrome C (12.4 K), aprotinin $(6.5 \mathrm{~K})$, somatostatin 28 (S28), somatostatin 14 (S14), neuromedin B (1.1 K).

To eliminate the possibility that the observed effect was dependent on the presence of the serum in the culture medium, NIH3T3 cells were cultured in serum free medium for $48 \mathrm{~h}$. In these conditions, growth of cells expressing sst 2 was decreased by $31 \pm 1 \%(n=3, P<0.01)$ compared to that of control cells. In addition, when NIH3T3 were cultured in serum free medium in the presence of the NIH3T3 cell mitogenic factor FGF2 (20) at $0.1 \mathrm{nM}$ for $48 \mathrm{~h}$, the proliferation of cells expressing sst 2 was reduced by $36 \pm 5 \%(n=3, P<0.05)$ compared with that of control cells. These results indicate that the reduction of cell growth in clonal cells expressing sst2 was independent of the presence of serum in the culture medium and lead to the speculation of a constitutive activation of sst2.

Expression of sst 2 in NIH 3 T3 cells caused activation of sst 2 by a somatostatin-dependent autocrine pathway. To answer the question of whether the sst2 expressed in NIH 3 T3 cells was constitutively active, we analyzed the first step in the sst 2 signaling pathway, i.e., the stimulation of the receptor by way of the production of endogenous ligand. To determine whether NIH 3 T3 expressing sst 2 might synthesize and secrete somatostatin, we first examined the endogenous production of somatostatin-like immunoreactivity in lysates from cells expressing, or not, sst2. Somatostatin-like immunoreactivity was undetectable in lysates from cells transfected, or not, with sst 2 or sst 1 expression vector. In contrast, in media obtained from cells ex- pressing sst2, the level of somatostatin-like immunoreactivity was $0.23 \pm 0.05 \mathrm{fmol} / \mathrm{ml}$ per $48 \mathrm{~h}$ of culture (mean $\pm \mathrm{SEM}, n=$ 3). Somatostatin-like immunoreactivity was not detectable in media from control cells or cells expressing sst1. These results indicate that cells expressing sst 2 secreted somatostatin-like immunoreactivity at concentrations in the picomolar range and sufficient to activate sst 2 and to induce stimulation of tyrosine phosphatase activity and inhibition of cell growth as previously reported (20).

To determine which somatostatin forms were present in cell culture medium, cells expressing sst2 were cultured for $48 \mathrm{~h}$ in DME containing 10\% FCS and pooled cell media were treated, as described in Methods, for analysis of somatostatinlike immunoreactivity. The analysis of fresh DME with $10 \%$ FCS was also performed to evaluate somatostatin-like immunoreactivity present in the added FCS. As illustrated in Fig. 2, when DME containing 10\% FCS was loaded on the Sephadex $\mathrm{G}_{50}$ column, a peak of somatostatin-like immunoreactivity with an elution volume of $153 \mathrm{ml}$ accounted for $66 \%$ of total immunoreactivity and coeluted with somatostatin 14 . When cell media from sst2-transfected NIH3T3 cells was loaded on the column, the total immunoreactivity was fourfold higher than that observed in DME containing 10\% FCS and a major peak coeluting with somatostatin 14 was identified. However, this peak that accounted for $61 \%$ of total somatostatin-like immu- 

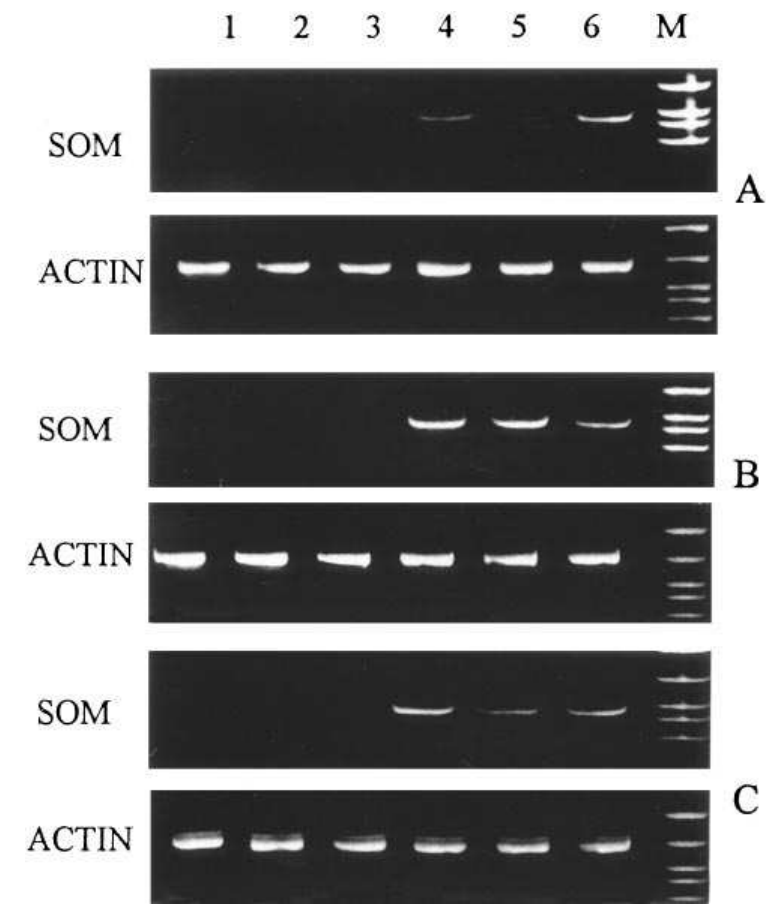

Figure 3. Effect of sst2 expression on steady state preprosomatostatin mRNA levels in NIH 3T3 cells. NIH 3T3 clonal cell lines containing the vector alone (control, lanes $1-3$ ) or expressing sst2 (lanes $4-6)$ were grown in 24-well plates $\left(6 \times 10^{4}\right.$ cells per well $)$ in DME in the absence $(A)$ or presence of $0.1 \mathrm{nM} \mathrm{FGF} 2(B)$ or in DME supplemented with $10 \%$ FCS $(C)$. RT-PCR assays of preprosomatostatin mRNA (Som) and $\beta$-actin mRNA (actin) were performed after $2 \mathrm{~d}$ of culture. The resulting PCR products were analyzed by polyacrylamide gel electrophoresis and ethidium bromide staining.

noreactivity occurred in 3-4-fold higher quantities in sst2NIH3T3 cell media $(0.35 \mathrm{pmol} /$ liter $)$ than in DME with $10 \%$ FCS ( 0.1 pmol/liter). A minor peak ( $9 \%$ of total immunoreactivity) with an elution volume of $57 \mathrm{ml}$ representing high apparent molecular mass immunoreactive materials was also detected in sst2-NIH3T3 cell media and could correspond to somatostatin proforms.

To further support the sst2-induced production of somatostatin in NIH 3T3 cells, we next examined the expression of preprosomatostatin mRNA by reverse transcriptase polymerase chain reaction (RT-PCR) analysis. As observed in Fig. 3 , preprosomatostatin mRNA transcripts were barely or not detected in the control cell line whatever the cell culture conditions. In contrast, the level of preprosomatostatin transcripts was clearly up-regulated in cell expressing sst 2 after $48 \mathrm{~h}$ of culture either in serum free medium, in absence or presence of FGF2 or in medium with $10 \%$ FCS.

Further evidence that the secreted immunoreactive somatostatin accounted for the inhibition of cell growth, we evaluated the effect of addition of antiserum to somatostatin in the cell culture medium. We observed that the exposure of cells for $96 \mathrm{~h}$ to anti-somatostatin antiserum did not modify the growth of control cells but increased the growth of clonal cell lines expressing sst2 (clone $2 / 5:+34 \pm 3.5 \%, n=4$; clone $2 / 1:+26 \pm$ $2.3 \%, n=3 . P<0.01$ ) (Fig. 4 ). These results indicate that somatostatin antiserum neutralized the effect of secreted somatostatin and reversed the inhibitory effect of sst 2 expression on cell growth.

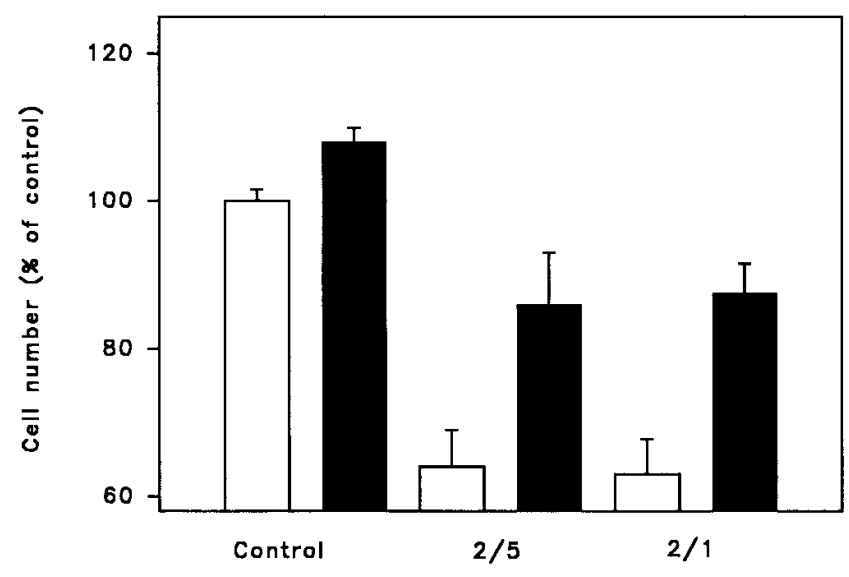

Figure 4. Suppression of the inhibitory effect of sst2 expression on NIH 3 T3 cell growth by antiserum to somatostatin. NIH 3T3 clonal cell lines containing the vector alone (control) or expressing sst $2(2 / 1$, $2 / 5)$ were grown in 24 -well plates $\left(6 \times 10^{4}\right.$ cells per well $)$ in DME with $10 \%$ FCS. After an overnight attachment, cells were treated (filled bars) or not (hollow bars) once daily with antiserum to somatostatin (final dilution 1:250) in a volume of $0.5 \mathrm{ml}$ for $4 \mathrm{~d}$. Then cell number was determined. Results are expressed as the percent of the value obtained for the control clone. Values are mean \pm SEM (vertical lines) of three (clone 2/1) or four (clone 2/5) experiments. Values of treated clonal cell lines are significantly different from nontreated cell lines $(P<0.01)$.

We can conclude from these results that stable expression of sst2 in NIH $3 \mathrm{~T} 3$ cells led to the expression of somatostatin 14 peptide. The produced sst 2 ligand activated sst 2 and promoted the creation of an autocrine inhibitory loop.

sst 2 expression up-regulated the expression of tyrosine phosphatase PTP1C. We examined whether the sst2-induced negative autocrine growth system affected the activation of the signal transduction pathway coupled to sst2, the tyrosine phosphatase PTP1C. Basal tyrosine phosphatase activity was assayed using tyrosine-phosphorylated poly [Glu,Tyr] as substrate (7). In cells cultured in DME with FCS, basal tyrosine phosphatase activity was increased by $29 \pm 3.7 \%$ (mean \pm SEM, $n=3, P<0.05)$ in NIH 3 T3 cells expressing sst2,compared with that of NIH $3 \mathrm{~T} 3$ control cells. Expression of sst1 in NIH $3 \mathrm{~T} 3$ cells had no effect on basal tyrosine phosphatase activity (not shown).

We then tested the effect of expression of sst 2 on the tyrosine phosphatase activity of PTP1C. When cells were cultured for $48 \mathrm{~h}$ in DME with FCS, immunoprecipitation of PTP1C using anti-PTP1C antibodies (36) revealed that in control cells, PTP1C activity was low after $48 \mathrm{~h}$ of culture in DME with FCS $(0.25 \pm 0.11 \mathrm{pmol} / \mathrm{mg}$ protein per minute). In cells expressing sst2, PTP1C activity was increased by 3-4-fold as compared to that of control cells indicating that expression of sst 2 constitutively increases PTP1C activity (Fig. $5 A$ ). As previously observed for tyrosine phosphatase activity in pancreatic cells (7), in control and sst2-transfected cells, PTP1C activity decreased when NIH3T3 cells reached confluency, after 4-5 d of culture. In these conditions, PTP1C activity was increased by $\sim 27 \%(P<0.05)$ in cells expressing sst $2(0.19 \pm 0.008 \mathrm{pmol} /$ $\mathrm{mg}$ protein $/ \mathrm{min}$ ), as compared to that of control cells $(0.15 \pm 0.006 \mathrm{pmol} / \mathrm{mg}$ protein $/ \mathrm{min}, n=3)$. We next examined the effect of expression of sst 2 on the PTP1C protein level by protein immunoblotting analysis with antiserum to PTP1C. 

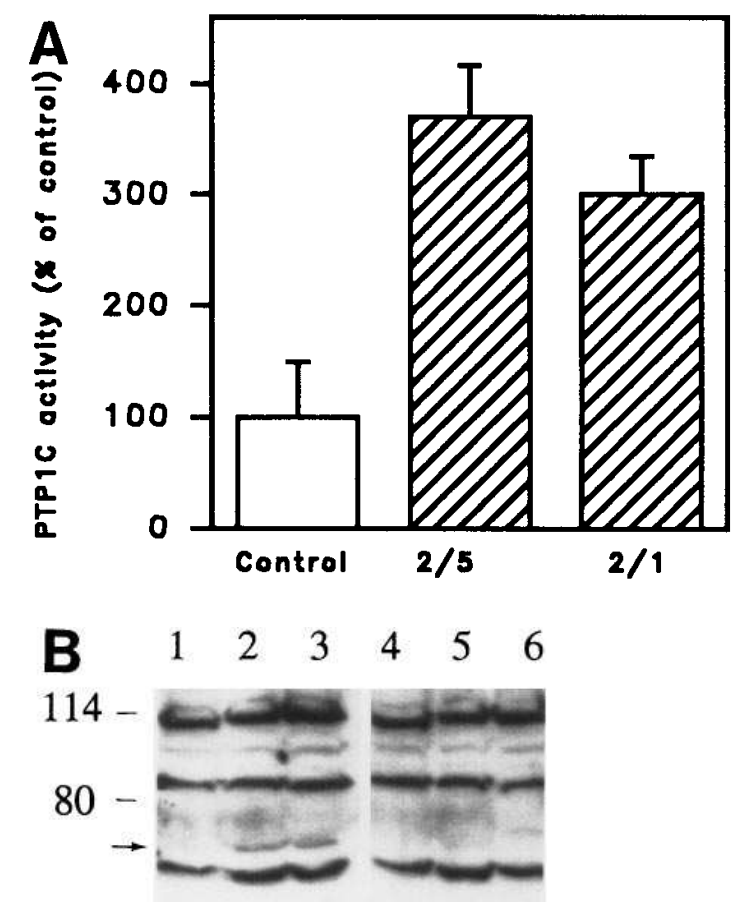

$49.5-$

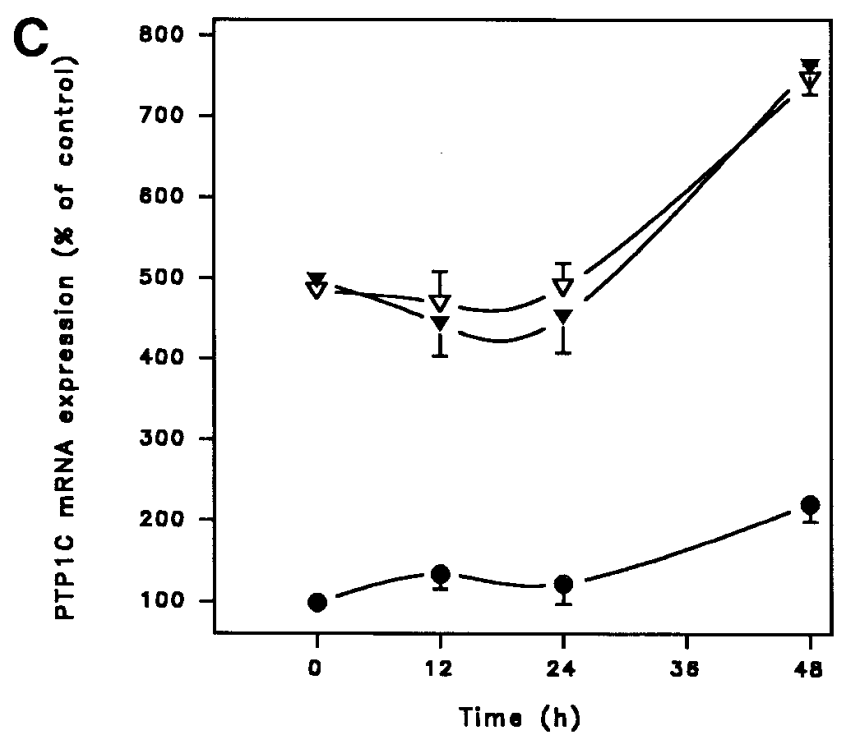

Figure 5. Effect of expression of sst 2 on tyrosine phosphatase activity $(A)$, protein $(B)$, and steady-state mRNA levels $(C)$ of PTP1C in NIH $3 \mathrm{~T} 3$ cells. NIH $3 \mathrm{~T} 3$ clonal cell lines containing the vector alone (control) or expressing sst2 $(2 / 1,2 / 5)$ were grown in DME with $10 \%$ FCS $\left(6 \times 10^{5}\right.$ cells per $100-\mathrm{mm}$ plate $)$ for $48 \mathrm{~h}$. (A) PTP1C was immunoprecipitated from cell lysates containing equal amount of proteins with rabbit polyclonal antiserum to the $\mathrm{COOH}$ terminal amino acids of PTP1C. Immunoprecipitates $(100 \mu \mathrm{l})$ were assayed for tyrosine phosphatase activity in the presence of $30,000 \mathrm{dpm}{ }^{33} \mathrm{P}$-poly(Glu,Tyr) for $5 \mathrm{~min}$ at $30^{\circ} \mathrm{C}$. Results are expressed as percent of activity of control clone and each point is the mean \pm SEM (vertical lines) of three experiments. PTP1C activity of control cells: $0.25 \pm 0.11$ pmol of phosphate released per min per $\mathrm{mg}$ solubilized protein. Statistical significance between control and clonal cell lines: $P<0.02$. (B) NIH 3T3 clonal cell lines $2 / 1$ and 2/5 (lanes 2 and 3, respectively) and NIH 3T3
After $48 \mathrm{~h}$ of culture in DME with FCS, both clonal cell lines expressing sst 2 contained PTP1C protein as shown by the presence of the $66 \mathrm{kDa}-\mathrm{PTP} 1 \mathrm{C}$ band in the two clones. In contrast, a barely detectable PTP1C band was observed in control cells (Fig. 5 B). Other bands which were detected by anti-PTP1C antibodies and preimmune serum, were suppressed in the presence of an excess of peptide and may represent non specific immunoreactive bands. Thus, the observed increase of PTP1C activity in sst2-expressing cells may result from the increased protein level of PTP1C. We then investigated the level of PTP1C gene expression by RT-PCR. The level of PTP1C transcripts increased markedly in both clonal cell lines expressing sst 2 compared with the low level of PTP1C mRNA in the control cells (Fig. $5 \mathrm{C}$ ). The increase of PTP1C transcripts in NIH3T3 cells expressing sst2 was also observed when cells were cultured for $48 \mathrm{~h}$ in serum free medium in the absence or presence of FGF2 (not shown). All these findings demonstrate that the expression of sst 2 in NIH 3 T3 cells caused a constitutive activation of PTP1C as a consequence of its increased expression.

To further support the role of the autocrine activation of sst2 in the up-regulation of PTP1C mRNA level, we examined the effect of somatostatin antibodies on the level of PTP1C mRNA. A $96 \mathrm{~h}$ treatment of cells in DME supplemented with $10 \%$ FCS in the presence of anti-somatostatin antibodies markedly reduced PTP1C mRNA expression in the clonal cell lines expressing sst2 (Fig. 6). In contrast, somatostatin antiserum did not modify the level of PTP1C mRNA in NIH 3T3 control cells. However, the down regulation of PTP1C mRNA in cells expressing sst 2 did not affect PTP1C activity which was not modify when cells were grown in the presence of somatostatin antiserum. The short time period of treatment with antiserum could account for the absence of effect on PTP1C activity.

To strengthen the role of PTP1C in the sst2-induced autocrine negative loop we first tested whether the blockage of tyrosine phosphatase activity can prevent the sst2-induced growth inhibition. When orthovanadate, a known inhibitor of PTP activity (7), was added for $5 \mathrm{~d}$ in the cell culture medium, the proliferation of NIH $3 \mathrm{~T} 3$ control cells was not significantly modified whereas in the clonal cell lines expressing sst 2 , the inhibitory effect of sst2 expression on cell proliferation was blocked (Fig. 7). Furthermore, PTP1C activity in cells expressing sst2 $(0.20 \pm 0.01 \mathrm{pmol} / \mathrm{mg}$ protein $/ \mathrm{min})$ was reduced by $67 \pm$ $6.5 \%(n=2)$ when cells were grown in the presence of vanadate whereas vanadate treatment did not significantly affect PTP1C activity of control cells. This suggested a role for tyrosine phosphatase activation in the sst2-induced negative

control cells (lane 1) were lysed and proteins were resolved by SDSPAGE on a $7.5 \%$ acrylamide gel, transferred to Immobilon membrane and blotted with antiserum to PTP1C (1:1000 dilution) in the presence (lanes 4-6) or not (lanes 1-3) of an excess of peptide used to raise antibodies. The detection of bands was perfomed using chemiluminescent reaction. $(C)$ The level of PTP1C mRNA from NIH 3T3 clonal lines, control $(\bullet), 2 / 5(\nabla)$ and 2/1 $(\boldsymbol{\nabla})$ was determined by RTPCR analysis at the indicated times. PCR products were quantified from ethidium bromide-stained polyacrylamide gels. Values are mean \pm SEM (vertical lines) of three experiments and are expressed as percent of values obtained from the control clone at time 0 . All values of clonal cell lines are significantly different fom control $(P<$ $0.01)$. 


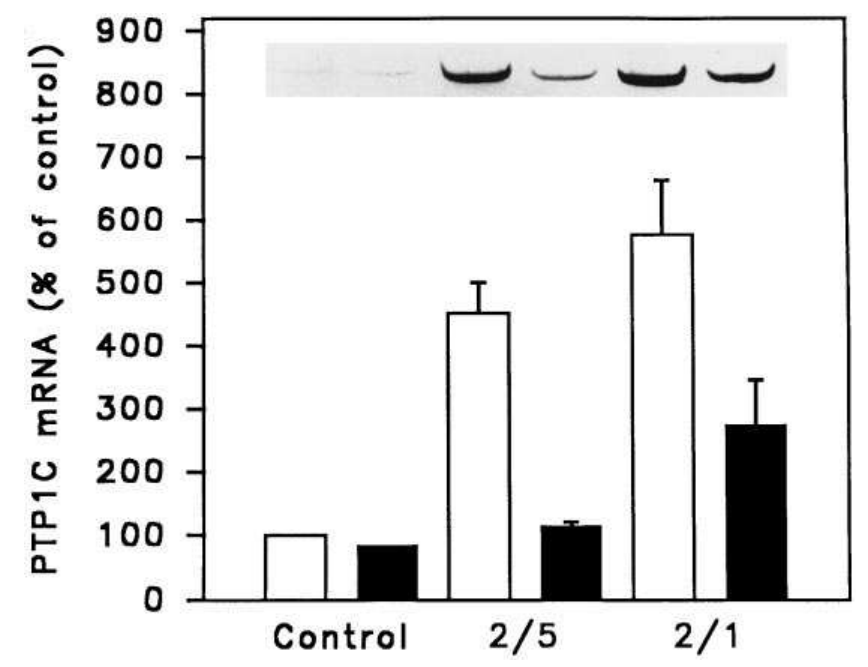

Figure 6. Effect of somatostatin antiserum on the steady-state level of PTP1C mRNA. NIH 3T3 clonal cell lines containing the vector alone (control) or expressing sst2 $(2 / 1,2 / 5)$ were grown in the presence (filled bars) or absence (hollow bars) of somatostatin antiserum for $4 \mathrm{~d}$ as described in Fig. 4. Then, the level of PTP1C mRNA was determined by RT-PCR analysis. PCR products were quantified from ethidium bromide-stained polyacrylamide gels. Values are mean \pm SEM of triplicate experiments and are expressed as percent of control value obtained from untreated cells. Statistical significance between untreated and treated clonal cell lines: $P<0.05$. Vertical lines indicate SEM. The insert shows representative PTP1C PCR products of one experiment.

growth effect. Then, the decrease of PTP1C protein level was induced by addition to the cell culture medium, of phosphorothioate antisense oligonucleotides directed against two selected sites of PTP1C mRNA, the start codon and 80 to $95 \mathrm{nu}-$ cleotides from the start codon. NIH $3 \mathrm{~T} 3$ expressing or not sst2 were incubated with $5 \mu \mathrm{M}$ anti-sense or sense oligonucleotides, added twice daily for $96 \mathrm{~h}$. Immunoblotting analysis revealed a 50\% decrease of PTP1C protein level after treatment of cells expressing sst2 with antisense oligonucleotides compared with the protein level after treatment with sense oligonucleotides (not shown). In cells expressing sst2, antisense treatment reduced the sst2-mediated inhibition of cell growth by $\sim 50 \%$ but had no significant effect on NIH 3 T3 control cell growth (Fig. 8). These results indicate that the inhibitory effect of sst 2 on cell growth is mediated, at least in part, by increased expression of PTP1C.

Effect of transfection of sst 2 expression vector on pancreatic tumor cell $B X P C 3$. To assess whether the sst2-induced negative autocrine loop could be observed on other cell types than NIH 3T3, human pancreatic tumor BXPC3 cells that do not express endogenous sst2 (20) were transfected with the sst2 expression vector. As observed in Fig. 9, expression of sst2 affected the proliferation of BXPC3 cells which was decreased by $\sim 35 \%$ compared with that of control cells. Furthermore, we observed that $\mathrm{BxPC} 3$ control cells produced somatostatinlike immunoreactivity and that expression of sst 2 induced an increase of somatostatin-like immunoreactivity secreted in the culture medium. Theses results demonstrated that in BXPC3 cells like in NIH 3T3 cells, sst2-induced negative growth regu-

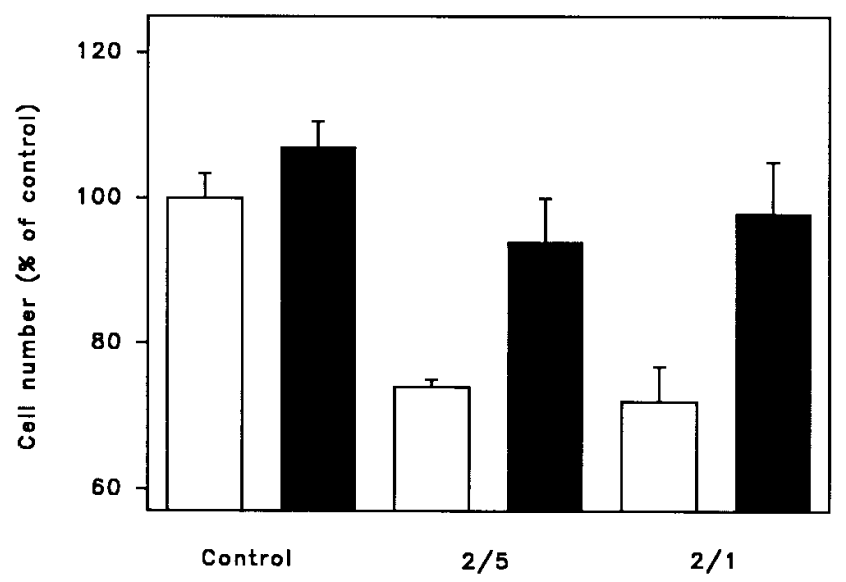

Figure 7. Effect of orthovanadate on sst2-induced NIH 3 T3 cell growth inhibition. NIH $3 \mathrm{~T} 3$ cells containing the vector alone (control) or expressing sst2 $(2 / 5,2 / 1)$ were grown as described in Fig. 1 and treated (filled bars) or not (hollow bars) once daily with $3 \mu \mathrm{M}$ orthovanadate for $5 \mathrm{~d}$ and the number of cells was determined. Results represent mean \pm SEM (vertical lines) of three experiments and are expressed as a percent of control value obtained from untreated cells. Values of treated clonal cell lines expressing sst2 are significantly different from non treated cell lines $(P<0.05)$.

lation is associated with an increase production of somatostatin-like peptide.

\section{Discussion}

Somatostatin functions as a growth inhibitory agent in a wide range of normal and neoplastic tissues $(2,3,8,9)$. Several mechanisms of actions have been postulated for the growth inhibitory effect of somatostatin and its analogues. Indirect ef-

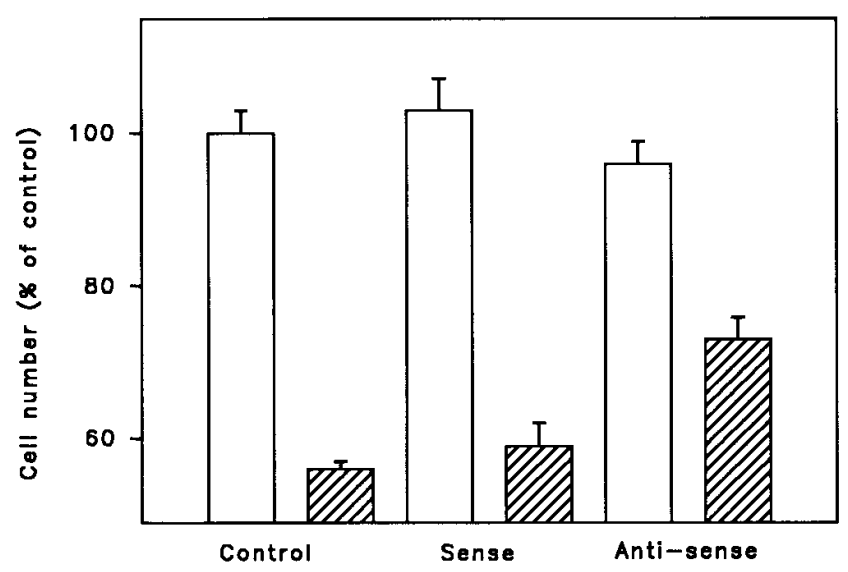

Figure 8. Effect of PTP1C antisense oligonucleotides on sst2-induced NIH 3 T3 cell growth inhibition. Cells containing the vector alone (hollow bars) or expressing sst2 (hatched bars) were grown in 24-well plates as described in Fig. 3. After overnight attachment, $5 \mu \mathrm{M}$ PTP1C sense or antisense phosphorothioate oligonucleotides were added or not (control) twice daily for $4 \mathrm{~d}$, then cell number was measured. Values are mean \pm SD (vertical lines) of triplicate wells and are expressed as percent of control value obtained from NIH 3 T3 control cells that did not receive oligonucleotides. The experiment was done twice. 

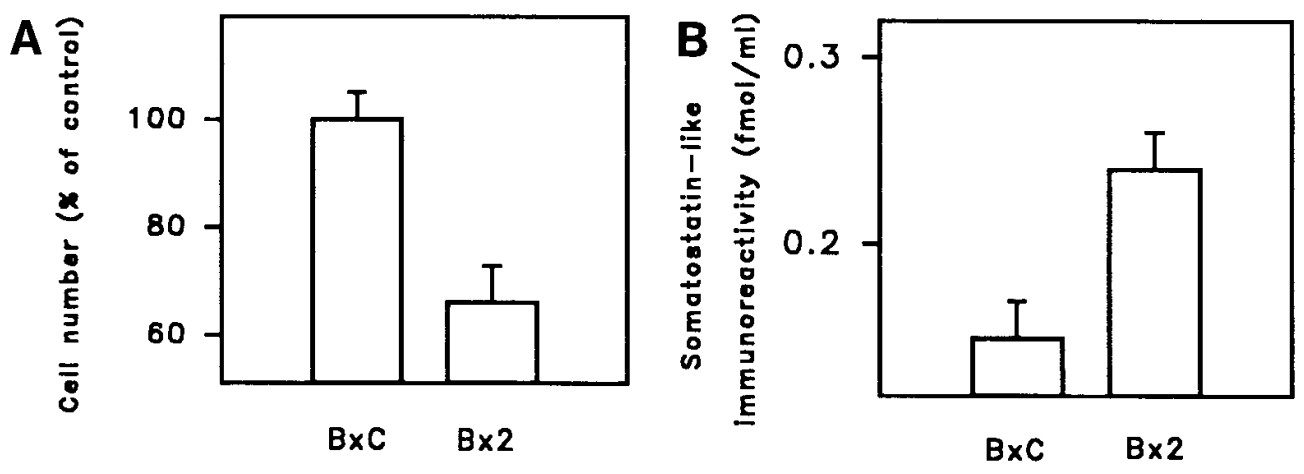

Figure 9. Effect of expression of sst 2 on $\mathrm{BxPC} 3$ cell growth $(A)$ and somatostatin-like immunoreactivity production $(B)$. Clonal cell lines were derived from BxPC3 cells stably transfected with the dicistronic vector alone $(\mathrm{B} \times \mathrm{C})$ and the vector encoding human sst $2(\mathrm{~B} \times 2)$, respectively (20). Cells $\left(30 \times 10^{4}\right.$ per 60 $\mathrm{mm}$ plate) were grown in DME supplemented with $10 \%$ FCS. After an attachment phase, cells were cultured in serum-free medium overnight and then cultured in medium containing serum for $72 \mathrm{~h} .(A)$ Cell growth was measured by cell counting. Results are expressed as per cent of control cell number. Values are mean \pm SEM $(n=4)$. $(B)$ Somatostatin-like immunoreactivity was measured in the culture medium by radioimmunoassay. Each point represents the mean \pm SEM $(n=3)$. Vertical lines indicate SEM.

fects may involved suppression of secretion of mitogenic growth factors and hormones, inhibition of angiogenesis and modulation of the immune system $(8,9)$. A direct inhibitory effect of somatostatin and analogues mediated through specific somatostatin receptors has been demonstrated on several somatostatin receptor-positive tumor cell lines of various origin $(8-13,31)$. Among the five cloned somatostatin receptor subtypes, we have recently shown that the somatostatin receptor sst2 mediated the antiproliferative effect of somatostatin analogues through the stimulation of a tyrosine phosphatase activity $(20,21)$, identified as PTP1C $(25,41)$.

In the present study, we have clearly established the intrinsic role of the somatostatin receptor sst 2 as a negative growth regulator. We have shown that expression of sst2 in NIH 3T3 cells causes a constitutive activation of the receptor which resulted from the induction of sst2 ligand and led to the generation of a negative autocrine growth-regulatory loop. Such a mechanism is supported by different observations. First, the inhibition of cell proliferation that occurred after stable expression of sst2 in NIH 3 T3 cells, independently of the presence of serum in culture medium, was associated with an increase in the steady-state level of preprosomatostatin mRNA as well as the production of endogenous somatostatin-like peptide. Second, characterization of immunoreactive forms provides evidence of the presence of somatostatin 14 form in media from cells expressing sst 2 and neutralizing secreted somatostatin 14 by somatostatin antibodies counteracted the sst2-induced inhibition of cell proliferation, indicating that suppression of the interaction between secreted ligand and sst2 receptors interrupted the sst2-induced autocrine loop. We also demonstrated that stable expression of sst 2 caused the amplification of the sst 2 signal transducer, the tyrosine phosphatase PTP1C. Expression of sst 2 induced a constitutive activation of PTP1C which resulted from an increase expression of PTP1C mRNA and protein levels and might be responsible, at least in part, for the propagation of the sst2-mediated antiproliferative effect of produced somatostatin-like peptide.

We have established that cells expressing sst 2 were capable of producing somatostatin 14 in cell media at concentration (0.2-0.3 pM) high enough to trigger a slight inhibitory growth response (7, 20-21). However, due to the well known short half-life of the peptide in body fluids as in cell culture medium (2), the detected somatostatin 14 concentration may reflect only a fraction of the really secreted peptide. Also, the se- creted ligand could act at a very short distance and bind neighboring sst 2 receptors at a high local concentration. Our demonstration that sst2 expression increased the steady state preprosomatostatin mRNA levels and somatostatin secretion in cell media raises the question of the signal transduction mechanism activated by sst 2 and involved in this effect. Both the expression of preprosomatostatin mRNA and somatostatin production are known to be modulated by a variety of stimuli (1-3) and somatostatin has been demonstrated to be capable of inhibiting its own secretion from somatostatin-producing cells through specific receptors (42). Studies to elucidate the nature of stimuli involved in the sst2-mediated up-regulation of preprosomatostatin mRNA may be now undertaken. As with many peptide hormones, somatostatin is synthesized as a precursor, prosomatostatin, that undergoes post-translational processing by specific endoproteolytic enzymes belonging to the subtilisin-like serine protease family. Processing occurs principally at the $\mathrm{COOH}$-terminal part of the molecule to generate the two biologically active peptides, somatostatin-14 and somatostatin-28, an $\mathrm{NH}_{2}$ terminally extended form of somatostatin-14 (43). Our results argue in favor of an endoproteolytic processing of prosomatostatin in NIH3T3 cells expressing sst2.

Coincident with the induction of sst2-ligand, our results clearly showed that expression of sst2 in NIH 3 T3 cells increased the activity of PTP1C as a result of increased expression of PTP1C mRNA and protein. PTP1C has been proposed to be a negative regulator of growth factor-induced mitogenic signaling pathways. Of interest is that PTP1C contains two srchomology domains (SH2) (22-24). The presence of these domains in various cytoplasmic signaling molecules suggests that this enzyme has a role in signal transduction by interacting with tyrosine-phosphorylated proteins. Indeed, PTP1C associated with activated growth factor receptors and inhibited growth factor-induced tyrosine phosphorylation and mitogenesis $(24,44)$. Furthermore, overexpression of PTP1C has been reported to be associated with growth inhibition and decreased growth factor-induced mitogenesis (45). Conversely, decreased level of PTP1C was associated with increased cell growth and growth factor-mediated cell responses (24). A role of PTP1C in the negative regulation of cell growth is also supported by the recent demonstration that severe hematopoietic dysregulation and overexpansion of colony stimulating factor-1 growth-independent of macrophage/monocyte populations in 
the mouse motheaten phenotype results from loss-function mutations in the PTP1C gene (46). Our demonstration that the expression of sst2 in NIH 3T3 cells induced an increased expression of PTP1C that resulted in constitutive activation of PTP1C argues in favor of the role of PTP1C in the negative control of cell growth mediated by sst 2 . The fact that blocking the PTP1C signal transduction pathway either with orthovanadate which inhibits PTP1C activity or with PTP1C antisense oligonucleotides which partially decrease PTP1C protein level, interrupted the sst2-induced autocrine inhibitory loop indicates that PTP1C is one of the component involved in sst2induced autocrine inhibitory loop.

The concept of autocrine/paracrine growth has been well documented for peptide growth factors (47). Although the somatostatin-receptor system has been proposed to play an autocrine/paracrine role in the negative regulation of cell growth, this concept has never been proven. We have demonstrated that sst 2 is the initial mediator of the inhibitory growth response and triggers the autocrine production of ligand and signal transducer which may act in concert to produce antiproliferative response. Interestingly, our results suggest that the sst2-induced autocrine loop is generated in another cell type lacking endogenous sst2, the human pancreatic tumor cell line, BXPC3 (20). We observed that control BxPC3 cells produced somatostatin-like immunoreactivity as reported for certain tumors and tumor cell lines (31-33). Furthermore, we demonstrated that expression of sst 2 resulted in a decrease of BxPC3 cell growth associated with an enhanced production of somatostatin-like immunoreactivity. These findings lead to speculate that the autocrine somatostatin-sst2 loop can exist in certain cells that express the sst2 ligand-receptor system and underlines the possibility that this phenomenom has a role in the negative regulation of cell growth. Constitutive activation of growth factor receptors through autocrine/paracrine mechanisms occurs frequently in cancer cells and is involved in carcinogenesis (47-48). Inversely, the loss of sst2 autocrine activation may contribute to deregulation of cell growth and be relevant in the course of tumor development.

\section{Acknowledgments}

We are grateful to Dr. G.I. Bell (Howard Hughes Medical Institute, University of Chicago) for providing sst1 and sst 2 cDNA. This work was supported by grants from Association pour la Recherche contre le Cancer (6755) and Conseil Régional Midi-Pyrénées (9200045).

\section{References}

1. Reichlin, S. 1983. Somatostatin part I and part II. N. Engl. J. Med. 309: 1495-1501 and 1556-1563.

2. Yamada, T., and T. Chiba. 1989. Somatostatin, in Handbook of Physiology. S.T. Schultz, G.M. Maklouf, editors. American Physiological Society, Bethesda, MD. Vol II:431-453.

3. Lewin, M.J.M. 1992. The somatostatin receptor in the GI tract. Annu. Rev. Physiol. 54:455-469.

4. Patel, Y., K.K. Murthy, E.E. Escher, D. Banville, J. Spiess, and C.B. Srikant. 1990. Mechanism of action of somatostatin: an overview of receptor function and studies of the molecular characterization and purification of somatostatin receptor proteins. Metabolism. 39:[Suppl 2]:63-69.

5. Raynor, K., H.L. Wang, M. Dichter, and T. Reisine. 1991. Subtypes of somatostatin receptors couple to multiple cellular effector systems. Mol. Pharmacol. 40:248-253.

6. White, R.E., A. Schonbrunn, and D.L. Armstrong. 1991. Somatostatin stimulates $\mathrm{Ca}^{2+}$-actived $\mathrm{K}^{+}$channels through protein dephosphorylation. $\mathrm{Na}$ ture (Lond.). 351:570-573.

7. Tahiri-Jouti, N., C. Cambillau, N. Viguerie, C. Vidal, L. Buscail, N. Saint-
Laurent, N. Vaysse, and C. Susini. 1992. Characterization of a membrane tyrosine phosphatase activity in AR42J cells: regulation by somatostatin. Am. J. Physiol. 262:G1007-1014.

8. Schally, A.V. 1988. Oncological applications of somatostatin analogues. Cancer Res. 48:6977.

9. Lamberts, S.W.J., E.P. Krenning, and J. C. Reubi. 1991. The role of somatostatin and its analogues in the diagnosis and treatment of tumors. Endocrin. Rev. 12:450-482.

10. Viguerie, N., N. Tahiri-Jouti, A.M. Ayral, C. Cambillau, J.L. Scemama, M.J. Bastie, S. Knuhtsen, J.P. Esteve, L. Pradayrol, C. Susini, and N. Vaysse. 1989. Direct inhibitory effects of a somatostatin analog, SMS 201-995, on AR42J cell proliferation via pertussis toxin-sensitive guanosine triphosphatebinding protein-independent mechanism. Endocrinology. 124:1017-1025.

11. Weckbecker, G., F. Raulf, B. Stolz, and C. Bruns 1994. Somatostatin analogs for diagnosis and treatment of cancer Pharmacol. \& Ther. 60:245-264.

12. Liebow, C., C. Reilly, M. Serrano, and A.V. Schally. 1989. Somatostatin analogues inhibit growth of pancreatic cancer by stimulating tyrosine phosphatase. Proc. Natl. Acad. Sci. USA. 86:2003-2007.

13. Bensaid, M., N. Tahiri-Jouti, C. Cambillau, N. Viguerie, B. Colas, C. Vidal, J.P. Tauber, J.P. Esteve, C. Susini, and N. Vaysse. 1992. Basic fibroblast growth factor induces cell proliferation of a rat pancreatic cancer cell line. Inhibition by somatostatin. Int. J. Cancer. 50:796-799.

14. Pan, G., T. Florio, and P.J.S. Stork. 1992. G protein activation of a hormone-stimulated phosphatase in human tumor cells. Science (Wash. DC). 256: 12515-1217.

15. Yamada, Y., S.R. Post, K. Wang, H.S. Tager, G.I. Bell, G.I., and S. Seino. 1992. Cloning and functional characterization of family of human and mouse somatostatin receptors expressed in brain, gastrointestinal tract and kidney. Proc. Natl. Acad. Sci. USA. 89:251-255.

16. Yasuda, K., S. Rens-Domiano, C.D. Breder, S.F. Law, C.B. Saper, T. Reisine, and G.I. Bell. 1992. Cloning a novel somatostatin receptor SST3, coupled to adenylate cyclase. J. Biol. Chem. 28:20422-20428.

17. O'Carroll, A.-M., S.J. Lolait, M. König, and L.C. Mahan. 1992. Molecular cloning and expression of a pituitary somatostatin receptor with preferential affinity for somatostatin 28. Mol. Pharmacol. 42:939-946.

18. Bruno, J.F., Y. Xu, J. Song, and M. Berelowitz. 1992. Molecular cloning and functional expression of a brain-specific somatostatin receptor. Proc. Natl. Acad. Sci. USA. 89:11151-11155.

19. Law, S.F., D. Woulfe, and T. Reisine. 1995. Somatostatin receptor activation of cellular effector systems. Cell. Signal. 7:1-8.

20. Buscail, L., N. Delesque, J.P. Esteve, N. Saint-Laurent, H. Prats, P. Clerc, P. Robberecht, G.I. Bell, C. Liebow, A.V. Schally, N. Vaysse, and C. Susini. 1994. Stimulation of tyrosine phosphatase and inhibition of cell proliferation by somatostatin analogues: mediation by human somatostatin receptor subtypes SST1 and SST2. Proc. Natl. Acad. Sci. USA. 91: 2315-2319.

21. Buscail, L., J.P. Esteve, N. Saint-Laurent, V. Bertrand, T. Reisine, A.M. O'Carroll, G.I. Bell, A.V. Schally, N. Vaysse, and C. Susini. 1995. Inhibition of cell proliferation by the somatostatin analogue RC-160 is mediated by somatostatin receptor subtypes SST2 and SST5 through different mechanisms. Proc. Natl. Acad. Sci. USA. 92:1580-1584.

22. Shen, S.H., L. Bastien, B.I. Posner, and P. Chrétien. 1991. A proteintyrosine phosphatase with sequence similarity to the $\mathrm{SH} 2$ domain of the protein-tyrosine kinases. Nature (Lond.). 352:736-739.

23. Plutzky, J., B.G. Neel, and R.D. Rosenberg. 1992. Isolation of src homology 2-containing tyrosine phosphatase. Proc. Natl. Acad. Sci. USA. 89: 1123-1127.

24. Yi, T., A. Mui, G. Krystal, and J. Ihle. 1993. Hematopoietic cell phosphatase associates with the interleukin-3 (IL-3) receptor b chain and down-regulates IL-3-induced tyrosine phosphorylation and mitogenesis. Mol. Cell. Biol. 13:7577-7586

25. Zeggari, M., J.P. Esteve, I. Rauly, C. Cambillau, H. Mazarguil, M. Dufresne, L. Pradayrol, J.A. Chayvialle, N. Vaysse, and C. Susini. 1994. Co-purification of a protein tyrosine phosphatase with activated somatostatin receptors from rat pancreatic acinar membranes. Biochem. J. 303:441-448.

26. Taylor, J.E., M. Theveniau, R. Bashirzadeh, T. Reisine, and P.A. Eden. 1994. Detection of somatostatin receptor subtype 2 (SST2) in established tumor and tumor cell lines: evidence for SST2 heterogeneity. Peptides. 15:1229-1236.

27. Reubi, J.C., J.C. Schaer, B. Waser, and G. Mengod. 1994. Expression and localization of somatostatin receptor sst1, sst2, sst3 messenger RNAs in primary tumors using in situ hybridization. Cancer Res. 54:3455-3459.

28. Amherdt, M., Y.C. Patel, and L. Orci. 1987. Selective binding of somatostatin-14 and somatostatin-28 to islets revealed by quantitative electron microscopy autoradiography. J. Clin. Invest. 80:1455-1458.

29. Aguila, M.C., W.L. Dees, W.E. Haensly, and S.M. McCann. 1991. Evidence that somatostatin is localized and synthesized in lymphoid organs. Proc. Natl. Acad. Sci. USA. 88:11485-11489.

30. Vanhagen, P.M., E.P. Krenning, D.J. Kwekkeboom, J.C. Reubi, P.J. Anker-Lugtenburg, B. Löwenberg, and S.W.J. Lamberts. 1994. Somatostatin and the immune and hematopoietic system; a review. Eur. J. Clin. Invest. 24:9199.

31. Nelson, J., M. Cremin, and R.F. Murphy. 1989. Synthesis of somatostatin by breast cancer cells and their inhibtion by exogenous somatostatin and 
sandostatin. Br. J. Cancer 59:739-742.

32. De Bruïne, A.P., J.E. de Vries, W.N.M. Dinjens, P.T. Moerkerk, E.P.M. Van der Linden, M.M.J. Pijls, J. Ten Kate, and F.T. Bosman. 1993. Human Caco-2 cells transfected with C-Ha-Ras as a model for endocrine differentiation in the large intestine. Differentiation. 53:51-60.

33. Reubi, J.C., B. Waser, S.W.J. Lamberts, and G. Mengod. 1993. Somatostatin (SRIH) messenger ribonucleic acid expression in human neuroendocrine and brain tumors using in situ hybridization histochemistry: comparison with SRIH receptor content. J. Clin. Endocrin. Metab. 76:642-647.

34. Levy, L., J. Bourdais, B. Mouhieddine, C. Benlot, S. Villares, P. Cohen, F. Peillon, and D. Joubert. 1993. Presence and characterization of the somatostatin precursor in normal human pituitaries and in growth hormone secreting adenomas. J. Clin. Endocrinol. Metab. 76:85-90.

35. Chomczynski, P., and N. Sacchi. 1987. Single step method of RNA isolation by acid guanidinium thiocyanate-phenol-chloroform extraction. Anal. Biochem. 162:156-159.

36. Cambillau, C., I. Rauly, P. Sarfati, N. Saint-Laurent, J.P. Esteve, M. Fanjul, E. Hollande, N. Vaysse, and C. Susini. 1995. Regulation of the SH2-containing protein tyrosine phosphatase PTP1C by glucocorticoids in rat pancreatic AR42J cells. Endocrinology. 136:5476-5484.

37. Fuhrmann, G., R. Heilig, J. Kempf, and A. Ebel. 1990. Nucleotide sequence of the mouse preprosomatostatin gene. Nucleic Acids Res. 18:1287.

38. Alonso, S., A. Minty, Y. Bourlet, and M. Buckingham. 1986. Comparison of three actin-coding sequences in the mouse; evolutionary relationships between the actin genes of warm-blooded vertebrates. J. Mol. Evol. 23:11.

39. Chayvialle, J.A., M. Miyata, P.L. Rayford, and J.C. Thompson. 1980. Effects of test meal, intragastric nutrients and intraduodenal bile on plasma concentrations of immunoreactive somatostatin and vasoactive intestinal peptide. Gastroenterology. 79:844-852.

40. Laemmli, U.K. 1970. Cleavage of structural proteins during the assem- bly of the head of bacteriophage T4. Nature (Lond.). 227:680-685.

41. Esteve, J.P., F. Lopez, L. Buscail, N. Delesque, N. Saint-Laurent, T. Reisine, G.I. Bell, N. Vaysse, and C. Susini. 1995. Association of tyrosine phosphatase SHPTP1 to SST2 somatostatin receptor subtype. Gastroenterology. 108:960a (Abstr.)

42. Park, J., T. Chiba, K. Yokotani, J. Delvalle, and T. Yamada. 1989. Somatostatin receptors on canine fundic D-cells: evidence for autocrine regulation of gastric somatostatin. Am. J. Physiol. 257:G235-G241.

43. Patel, Y., and A. Galanopoulou. 1995. Processing and intracellular targeting of prosomatostatin-derived peptides: the role of mammalian endoproteases. Somatostatin and its receptors in Ciba Foundation Symposium. 190:2650 .

44. Uchida, T., T. Matozaki, T. Noguchi, T. Yamao, K. Horita, T. Suzuki, Y. Fujioka, C; Sakamoto, and M. Kasuga. 1994. Insulin stimulates the phosphorylation of $\mathrm{Tyr}^{538}$ and the catalytic activity of PTP1C, a protein tyrosine phosphatase with Src homology-2 domains. J. Biol. Chem. 269:12220-12228.

45. Matozaki, T., T. Uchida, Y. Fujioka, and M. Kasuga. 1994. Src kinase tyrosine phosphorylates PTP1C, a protein tyrosine phosphatase containing Src homology-2 domains that down-regulates cell proliferation. Biochem. Biophys. Res. Commun. 204:874-881.

46. Shultz, L.D., P.A. Schweitzer, T.V. Rajan, T. Yi, J.N. Ihle, R.J. Matthews, M.L. Thomas, and D.R. Beier. 1993. Mutations at the murine motheaten locus are within the hematopoietic cell protein-tyrosine phosphatase (Hcph) gene. Cell. 73:1445-1454.

47. Sporn, M.B., and Roberts A.B. 1992. Autocrine secretion. Ann. Intern. Med. 117:408-414.

48. Kondoh, G., N. Hayasaka, Q. Li, Y. Nishimune, and A. Hakura. 1995. An in vivo model for receptor tyrosine kinase autocrine/paracrine activation: auto-stimulated KIT receptor acts as a tumor promoting factor in papillomavirus-induced tumorigenesis. Oncogene. 10:341-347. 